\title{
Education and urban development in Koya city
}

\author{
Khidir Masum Hawrami \\ Koya University, Kurdistan Region, Iraq
}

"We recognize cities and towns as centres of civilization, generating economic development and social, cultural, spiritual and scientific advancement. We must take advantage of the opportunities presented by our settlements and preserve their diversity to promote solidarity among all our peoples."

Principle II of the Istanbul Declaration on Human Settlements 1996.

\begin{abstract}
Education is an important factor to provide human resources with skills and knowledge that are requi red for nation building. In this paper, Koya city in Kurdistan region-Iraq is selected as a case study, exploring how education has influenced the development of this city from the last cen tury until the present day. A historical background about the education in Koya city will be explained, and the factors that lead to the success of the education process will be assessed.
\end{abstract}

\section{Historical background}

Koya is a small city which is located $60 \mathrm{~km}$ east of the capital of Kurdistan, Erbil. Koya was on the line of trade between Tabriz in Iran and Welati Mosul (Mosul Province, now in Iraq) and Haleb (Aleppo, now in Syria), during the Ottoman Empire. This strategic location of Koya led to the movement of people from the surrounding villages and from different areas in Kurdistan, seeking work opportunities, or to run away from tribal conflicts. In 18th to 20th centuries, several religious leaders from different parts of Kurdistan moved to Koya, especially the prominent known scholars, to practise religious requirements and teaching. Mosques then became centres of education, reciting prayers and Islamic obligations. In addition, the Mosques became a centre of social gatherings, with everyday discussions, which varied from politics, poems, oral history and community problems [1]. 


\section{Religious education}

Until the end of the 19th century, Religious Education was the only topic to teach, as the Mullas "scholars" (religious male teachers or clerks) taught subjects related to the Religious Education. Students from different parts of Kurdistan and beyond were moved to Koya to obtain education. This environment made Koya a key location of prominent leaders in poets, religion and political life, making it the leading centre for education, literature and political activities. In 1900 there were more than 16 mosques in Koya that c ould accommodate more than 500 students. Teaching was divided into three stages:

Primary stage: The students we re usually children from age 4 years and upwards. The student learnt to read the Quran and write. This was usually conducted in a room in the Mosque or at home called Sukhtakhane (school). They were taught by Faqi. Female Faqi also were existed; these were to teach girls. In addition to Arabic, Persian was also taught on demand. Usually the teaching was free or for very little money. By 1900, the re were 16 of Sukhtakhane for boys and 6 for girls.

Faqi stage (religious student) divided to Sukhta stage and Mustaed stage (similar to Azhar University in Egypt, at that time)

Sukhta stage: As they became older, ge nerally teenagers, they had the capability to read and write the Quran. They were taught by Mustaid, most of the studies were introductions to various religious sciences, which lasted for a period of 5 to 7 years. At the end of this stage many of them left further education and became teachers of primary stage or they were going to villages to do Islamic practises for the villagers. Very few from this stage progressed to the next stage.

The Mustaed (means ready to become Mulla): This stage was more difficult, they were taught by an experienced scholar Mulla. He must to know all the 12 branches of Islam and sci ences (grammar, linguistic morphology, rhetoric, jurisprudence, principle of jurisprudence, logistics, literature, Islamic doctrine sciences, philosophy, astronomy, mathematics and geometry and interpretation of Quran). By the end of this stage, the Mustaed will be learnt various fields of Islam. When the teacher is satisfied with his student's ability in all sciences, then he granted them the certificate of knowledge of Islamic sciences. When they received their certificates, the whole community would celebrate for several days with them. Today we can compare these three sta ges as primary school, preparatory school and university, similar stages of teaching were exist at Azhar University in Egypt at that time.

After graduation, the graduate would become a $\mathrm{M}$ ulla who could teach students in the all stages. The teachers were ranked, the more knowledge they had the higher their rati ng would be. Koya usually could accommodate more than 500 students. Mosques also were like dormitories for them [2,3].

\subsection{Modern schools}

In 1880, the first modern school opened in Koya city. This school was for the children of Ot toman officials, however, it clo sed later. In 1890, the Ottoman 
Empire opened schools in Baghdad, Kirkuk, Mosul, Sulymania and Koya cities. In these schools they were ta ught in Turkish. In Koya, the primary school was called primary Koysinjaq School. The first group graduated from 6th years include:

1. Abdul Wahid Haji Agha Mustafa (1890-1975): After finishing primary school, Mr Mustafa went to Mosul to study at Ru shdia military school and then to military college in Istanbul. After graduation he became an officer in the Ottoman Empire, at same time he went to music school to learn music. Mr Mustafa participated in the First World War at the Russian front line; he was injured on the front line and was treated in Germany. During his stay there, he learned western music. After the collapse of Ottoman Empire and creation of new Iraq, he returne $d$ to Iraq and became military office $r$ at Bridger Musa Al-Kazam and the head of Royal Music Orchestra in Baghdad. He was the first person to bring music with manuscript to Kurdistan and established first orchestra in Sulaymania.

2. Sabir Haji Abdulla, Similar to Abdul Wahid Mustafa, he went to Istanbul and became an officer in the Ottoman Empire and returned to Iraq and became an officer in the Iraqi Army. Later, he became the head of police in the capital Baghdad.

3. Aziz Agha Abdulla Agha was also a Military Officer in the Ottoman Empire. He returned to Iraq and stayed in Koya.

4. Said Hasan Said Amin was a military officer in the Ottoman Empire. He returned to Iraq and his last job was the head of military camp in Erbil.

5. Said Husain like his brother Said Hassan went to Istanbul and became a military officer in the Ottoman Empire when the Iraqi state established he returned to Iraq.

6. Masum Khidir Hawrami: After finishing primary school he went to further studies in Da $r$ Alkhelafa in Kirkuk. He then becam e vice manager in Khanaqin, later he became imam and lecturer in the Great Mosque in Koya. He became a prom inent scholar in Kurdistan; students came to him from different parts of Kurdistan.

7. Jamel Khidir Hawrami died at a young age.

8. This group was regarded as the first group of graduates from the primary Koysinjaq School, not from religious schools. After World War I, the school was closed.

However, when the British Empire occupied Iraq and created the new Iraq by annexing Kurdistan region to it, the modern British style schools opened in Iraq. In May 1920 first new primary School in K oya was opened, by moving 30 students from primary stage from Sukhtakhane to the modern school. In 1923, the first two girls went to study with boys; their names were Naj eba Mulla Muhammad Jalizada and Najea Muhammad and in 1928 another two girls enrolled at the same school and their names were Latefa Mulla Sediqi Nazanini and Najea Abdul Rahman Sharaf.

In 1933, the first school for girls was opened and then the number of schools was increased in Koya city to have all the stages [2-4]. I n 2003, Koya 
University was established, students from different parts of Kurdistan and Iraq are joining this new modern university.

Koya is seen as an educ ation centre which leads to activate the market, enhance economy of the city; besides, supplying the city with expertise in varies fields.

Koya as mentioned before is one of well-known centres of education in Kurdistan. The city is $\mathrm{p}$ layed a prominent role in Kurdish inspiration, national rights and Kurdish uprising movements. A prominent leaders from this city like the great poet Haji Qadiri Koya, reformist Mallay Gawra, poet Dildar and current president of Iraq Sir Talabani and several other people which took important positions in Kurdish history.

The possible success and advances in education in Koya compared with other cities in the region may be due to that Koya never being an extension of tribes and its regu lations, in comparison with other cities in Kurdistan. This environment provides facility for education and liberalism life, particularly for female education which was rare to see in the whole of Iraq at th at time, especially young girls going to the same school with boys. This environment provided harmony and peace between various religions and believe rs in Koya, up to the present day.

On the other hand, due to the structure of Koya people, as they do not belong to one source and/or tribe, in the genetic point of vi ew, Koya was a f actor to enlarge gene pool and increase genetic diversity, as this can be explained that when gene pool increased the probability of acquiring genetic diseases will be reduced.

\section{Education and urban development}

The majority of the population of the world are living in urban areas, it is predicted by 2030 , it will reach $80 \%$ of the expected world population total of 8.6 billion [5].

This rapid urbanisation raises problems of the urban sustainable development. Ludwig et al. [6], found that there is a clos e association between education and urban development, as hi s study shows that students live in poor urban neighbourhoods in USA a re at greater risk for school failure. In Koya city like most cities in the developing countries, we are faci ng social problems, like unemployment, poverty and $\mathrm{r}$ apid growth of population and environmental pollution and poor infrastructures. All these problems are facing our s ociety. Therefore, it is important that universities provide the cities with knowledgeable and skilful graduates to find solutions for all these problems in cooperation with local government and outline the strategies and priorities to achieve a sustainable city development.

Similar strategies initiated in East Asia by World Bank in 1988, which have four major themes: liveability, competitiveness, good governance, and bankability [7, 8]. Similar strategies can be applied in Koya city for sustainable development. For example: 
Liveability: Koya city can be more Liveable if we could find some problems facing the city like: water and electricity shortages, better roads, job opportunity, better health services, housing, recreation facility, restau rants and hotels and healthy environment.

Competitiveness: To attract in vestments by creating sound atmosphere of competitiveness. Promote private sectors, revitalise factories which were existed in Koya and build new factories, Promote agriculture and local products.

Good governance and management: Local government should have the necessary power in management and remove all restrictions imposed by central government regulations and allocating necessary budget to do work.

Bankability: Financial help for small business, good banking account, given loan with small interest rate, spending local rev enue on Koya projects instead going to the centre, petrodollar share for the city according to the constitution.

\subsection{Possible solutions of urban problems}

The possible solutions of urban problems include:

1. Systematic development of urban centres and creation of job opportunities: One important solution of our-urban problems is the systematic development of the fast growing urban cities and planning an inv estment programme which could give rise to a large number of well distributed visible urban centres throughout the country [9].

2. Regional planning with city planning: Urban planning is almost city centred. There should be regional planning along with city planning to solve the problem.

3. Encouraging industries to move to backward area: It should be encouraged to open newer and heavy industries in the noticeable backward areas.

4. Municipalities to find own financial resources: If roads are prop erly maintained, it provides sewage system, supply drinking water and electricity. It is nece ssary that private $t$ ransportation be encouraged. Privately operated transport services will charge a little more fare.

5. Construction of new houses and flats: The borough councils should give permissions to build more houses and flats. It should also have a policy in place for the quality of a ccommodation to a fixe $\mathrm{d}$ minimum standard. Although such policy is too ambitious, it can be implemented.

6. Homelessness: The local gove rnments should find ways an d means to accommodate homeless people.

7. Job training and business development: The 1 ocal governments should provide job training and business development opportunities to enhance their communities by significantly changing the liv es of young adults for the better. 


\section{Conclusion}

As population grows the urbanisation of society is inevitable. Urbanisation leads to an increased impact on the environment. The impact of growth on all areas of society must be acknowledged. Sustainable growth requires an evolution in the way urban areas carry out their activities such as resource use and the movement of people and goods. The physical infrastructure in addition to social and economic processes must evolve to acknowledge the challenges of growth.

Sustainable urban development implies a process by which sustainability can be attained, emphasising improvement, progress and positive change, incorporating both environmental and s ocial dimensions. Sustainable urban development also highlights the need for reform of market mechanisms to achieve environmental goals and the achievement of a balan ce with social and economic considerations.

Education is an important factor for growth and economic development of the city. Education in Koya is one of the important resources for the city revenue and city expansion. Economic development is the sustained, rigorous actions of policy makers and communities that promote the standard of liv ing and economic health of a specific area. Therefore, there is close relationship between education and economic development in the community. Koya University can graduate professional expertises that are re quired for the city development in varies fields. These g raduates can make substantial contribution for providing solutions to the urban problems.

\section{References}

[1] W. R. Hay, Two years i n Kurdistan, experiences of a Political Officer 1918/1920, London 1921, pp. 125-144.

[2] Mohammed Bin Abdullah Al-Jalizada (the Great Mulla) and his Scientific Efforts, Jawad Faqe Ali, Erbil 2006. (Originally, the reference is in Arabic).

[3] The History of Ko ya, Second Edition, Tahir Ahmed Hawezi, Bag hdad, 1984. (Originally the reference is in Kurdish).

[4] A Page of the Kurdish Music History, Khidir Masoom, Kurdistani Nwe, Issue No. 56, 1988. (Originally the reference is in Kurdish).

[5] United Nations, Department of Economic and Social Affairs, Press Release of 24 March 2004.

[6] Ludwig J, Ladd HF, Duncan G J. Urban Poverty and Educational Outcomes Brookings-Wharton Papers on Urban Affairs, 2001.

[7] Rasoolimanesh SM, Badarulzaman N, Jaafar M. Achievement to Sustainable Urban Development using City Development Strategies: A C omparison between Cities Alliance and the World Bank definitions, Journal of Sustainable Development, Vol. 4, No. 5, October 2011.

[8] Frederick Harbison. Human Resources as t he Wealth of Nat ions, Proceedings of the American Philosophica, 1971, vol. 115, No. 6, Dec., pp. 426-431.

[9] http://www.publishyourarticles.net/knowledge-hub/economics/what-are-thesolution-of-urban-problems.html 